41 Oldemorstofts friheder bekræftet Flensborg 4. februar 1850 og af Frederik VII 16. februar 1851, Samlingen af dokumenter for Oldemorstoft

42 Hans Christian Jessen bevilges kro privilegier 6 april 1868, Samlingen af dokumenter for Oldemorstoft. Afvisningen af skattefrihed bekræftes i Berlin i december 1889 som svar på en klage fra Hans Christian Jessen, Bov lokalarkiv A119

43 Konfirmationsbrev dateret 31. oktober 1699, RAA Flensborg Amtstue 1

44 Bartholdy 2007, s. 29

45 Thiset, 1900, s. 317-18, Bartholdy, 1971, s. 580, Hiort-Lorenzen \& Thiset, 1908 , XI-XIII

46 Bojesen, 1911, s. 17, Bartholdy, 1971, s. 151

47 Thiset, 1900, s. 318
48 Zeitschrift der Gesellschaft für die Geschichte der Herzogthümer Schleswig Holstein und Lauenburg, 1983, s. 184 185

49 Privilegier til Oldemorstoft dateret 12 juli 1784, 22. januar 1701 og 16 . marts 1733. Brev fra rentekammeret til Herredsfogeden i Vies Herred dateret 19 december 1702, SAF XII HS 00962, Band 114

50 Christian V spiste middag på Oldemorstoft flere gange, mens Christian den IV ofte overnattede. Marquard, 1918, s. 417 og 452

51 Clausen, 1991, s. 73

52 Jespersen, 2015, s. 24

53 Juhler, 1942, s. 152

54 Poulsen, 1988, s. 59, Ethelberg m.fl. 2003 , s. 644

55 Henningsen, 2001, s. 319-322

\section{En vækkelse på Als, der fostrede en salmedigter}

\author{
Af Jens Lyster
}

Hidtil har det været almindeligt antaget, at gudelige vækkelser aldrig nåede frem til Als, i alt fald ikke før efter 1770. En bog, der i 1990'erne dukkede op på en containerplads, rykker ved dette billede. Den rummer tre opbyggelige skrifter med blandt andet 180 herrnhutiske sange fra årene 1745-1755 og stammer fra Landsbyen Blæsborg i Ketting Sogn på Als. Her skal det undersøges nærmere, hvad denne gamle bog kan fortælle os om forfatteren og hans religiøse liv, herunder hvordan han mødte "den glade pietisme", herrnhutismen, der forløste ham som digter.

\section{Containerarkæologisk fund}

Vores nye viden om en tidlig vækkelse på Als har vi kun takket være den ædle videnskab containerarkæologien - skam få den, der tænker ilde derom! ${ }^{1}$ - hvis betydning i disse smid-væk-tider ikke noksom bør påskønnes. En dag i begyndelsen af 1990'erne så den historisk interesserede lærer Christian Fægteborg fra Østerholm ved Nørreskoven på Als sit snit til at redde en gammel bog fra den visse destruktion på containerpladsen i Guderup. Han måtte dog først trodse skældud fra opsynsfolk, der henholdt sig til et kommunalt reglement om det forbudte i bortfjernelse af genstande fra containere. Men Fægteborg holdt fast på bogen og vedblev som god sønderjyde at holde fast! For denne dåd i Danmark og for et efterfølgende generøst og årelangt udlån af fundet havde en hosebåndsorden til finderen været på sin plads, men da det ikke tilkommer mig at uddele ordener, vil jeg i stedet med dyb taknemmelighed lade nedenstående undersøgelse være tilegnet hans minde. Christian Fægteborg døde den 21. september 2015.

Den bjergede bog, der i dag efter den snarrådige finders ønske er overdraget til Det Kongelige Bibliotek, er i alle henseender et unikum. Den er et provinsbogtryk på det jævne med simple træskårne friser og vignetter. Bogen måler 17x10 cm og holdes sammen af et almuebind af træ, bundet sammen af en simpel læderryg. På et hvidt blad før titelbladet står: "Peter Jørgensen Moes af Igen [Egen] den 14 Juli 1815". Mere om ham senere. 
Bogen er et samlebind omfattende tre ukendte skrifter, alle forfattet og udgivet af en ukendt Peter Ernst. Det første og største skrift (med i alt 128 blade), der også er det eneste med trykkeåret anført, bærer titlen²: "Jesu sair og vunders frygt Det er nogle nye salmer eller messianiske sange, bygget på de hellige patriarkers, profeters, apostles og Luthers grundvold, som er Jesus Kristus, Jakobs Gud og Israels frelser, hoilke er enfoldigt af den hellige ånd, i kraft af ordet om Jesu død, i en levende erkendelse ved Guds nåde, $i$ Lammets blods kraft og hans hellige vunders hemmeligheders virkninger, lys og glans, erfaret og fremstillet af P. Ernst. Trykt $i$ året 1756" (af mig herefter forkortet JS).

Hvor skriftet er trykt, er det op til forskningen at afsløre. ${ }^{3}$ Ligeledes røbes forfatterens identitet ikke med et ord - i alt fald ikke efter gængse biografiske normer - ej heller, hvor i riget han lever. At han ikke bor i Norge fremgår indirekte af, at han i forordet aftrykker et brev, afsend af taknemmelige norske brugere af hans salmer. Så udbredte er de altså blevet! Af skriftets omfang og af finurlige poetiske eksperimenter må man skønne, at forfatteren har ordet så meget i sin magt, at han må have været lærd og studeret.

Efter en fortale på 22 sider, dateret "den 12. maj 1755. P.E." begynder salmedelen, der omfatter 159 salmer af stærkt varierende længde. Adskillige rummer mere end 20 strofer. Den længste, nr. 155, har 31 strofer. I adskillige salmer er der forbønner for kongen, dronningen og den kongelige familie, ${ }^{4}$ men påfaldende uden antydning af kongerøgelse. ${ }^{5}$

I umiddelbar forlængelse følger salmerne nr. 160-187 med dette selvstændige titelblad:

"Nogle få salmer om en arm synders nådesgang og pleje hos den tro hyrde vor korsfestede frelser, forfattet af P.E." (Forkortet NfPs). ${ }^{6}$

Dette titelblad oplyser desuden, at skriftet "Findes til købs på Vajsenhusets Boglade". På bagsiden af titelbladet står en tilladelse til, at skriftet må trykkes i overensstemmelse med Det teologiske Fakultets protokol. ${ }^{7}$ Når denne tilladelse mangler ved de to øvrige skrifter, er det nærliggende at konkludere, at de ikke har været igennem den lovpligtige bogcensur, men er blevet distribueret i det skjulte uden øvrighedens vidende. Efter de nummererede salmer 160-187 følger register over samtlige salmer. Man kunne forvente, at registeret ville anføre 187 salmer, men tallet er kun 173. Salmerne nr. 13-26 mangler således, såvel i deres naturlige sammenhæng som i registeret, så måske er de aldrig udkommet? Eller måske har de stået i den samling, som digteren har sendt til brødrene i Norge?
Skriftet indeholder hovedparten af Peter Ernsts salmer og et forord, dateret 12. maj 1755, hoori han beretter om salmernes tilblivelse. Det eneste skrift med trykkeåret anført.

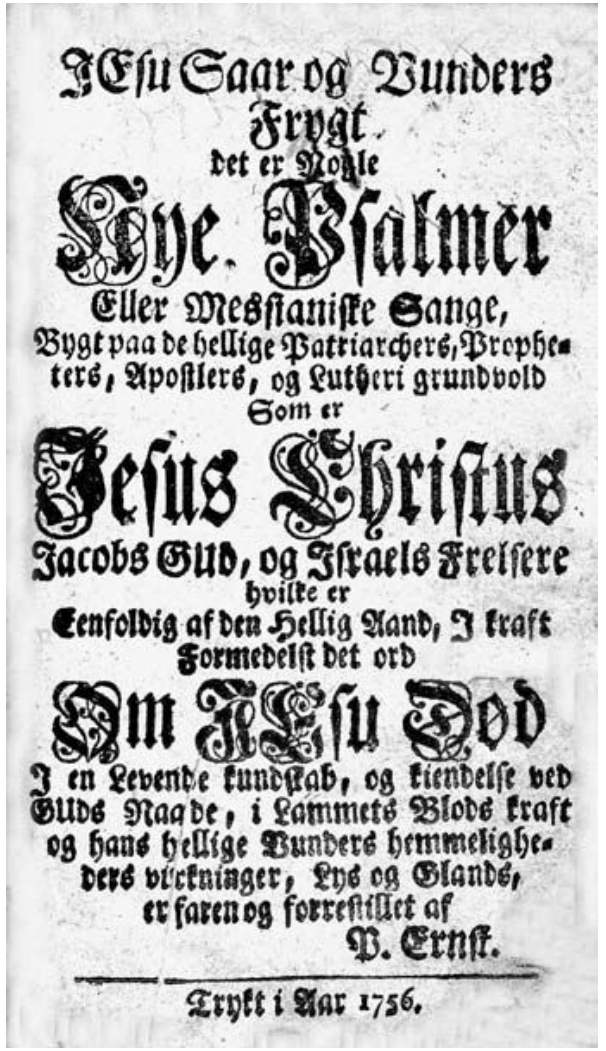

Samlebindet rummer endnu et skrift af Peter Ernst med dette titelblad: "Hjertets bekendtskab med Gud og Lammet. Det er et vidne om Guds kærlighed og nåde ved vor frelsers Jesu Kristi blod og hellige sår og vunders salve, erfaret af den Helligånds oplysning $i$ Jesu blods og lidelses kraft, og enfoldigt fremstillet $i$ en levende troens erkendelse, Gud, i den korsfastede frelser, til ære og lov. Af P. Ernst" (forkortet HB). ${ }^{8}$

Skriftet har sin egen paginering og sidetællingen 4-174. Det indledes med en fortale, der er dateret "den 10. april 1755. P.E." Derefter følger 11 kapitler, hvoraf kap. II-VIII fortrinsvis er prosa, men med indstrøede vers, mens kap. IX-XII rummer salmer og sange.

Det er dette forfatterskab, der er omend ikke faldet ned fra himlen, så dog dukket op som en stor overraskelse for den etablerede forskning i brødremenighedens historie, der fortrinsvis bygger på arkivstudier i Herrnhut og Christiansfeld. Disse studier registrerer og analyserer de 
censurerede tiltag i brødremenighedens aktiviteter og de organiserede medlemmer af menigheden. Ved det nye bogfund foreligger der pludselig et uberørt forfatterskab, der giver os direkte indblik i en adskilligt tidligere åndelig grøde, oplevet, erfaret og beskrevet af et menneske, der havde viljen og evnen til at give sig til kende, men uvist af hvilken grund aldrig lod sig organisere og registrere. ${ }^{9}$

\section{Den hidtidige forskning}

Hidtil har gudelige vækkelser på Als først været kendt efter 1770 og i Egen Sogn, hvor sognepræst Johann Joachim Hansen Ahrends virkede fra 1763 til 1785. Han var ikke blot en lærd mand, men "en af Herrens hellige Præster", og hver søndag bad han ved prædikenen Herren om at forøge "den lille Flok". Herrnhutiske brødre kom rejsende og holdt forsamling i Egen 3-4 gange om året, og folk kom langvejs fra. Også enkelte fra Ketting tog til møderne i Egen. I 1775 var der i Egen en lille flok troende sjæle, for hvem skrædderen Christian Petersen holdt forsamling hver søndag. Hos ham kunne de åndeligt søgende få vejledning. En gårdmandsdatter fra Elstrup, Theodore Jakobsen, blev vakt, og ligeså gårdmandsfamilien Schmidtmann, hvor sønnen Georg trådte i brødremenighedens tjeneste og virkede som missionær blandt eskimoerne i Labrador i 43 år. Også i landsbyen Dyndved i Egen Sogn var der troende gårdmandsfamilier. To døtre af gårdmænd blev gift med hver sin hedningemissionær og rejste, den ene til dansk Vestindien, den anden til Surinam i den nordøstlige del af Sydamerika. I 1775 var der på hele øen Als 70 personer, der sluttede sig til brødremenigheden. Flere rejste efter 1773 til Christiansfeld, således den 25-årige Carl Ludvig Clausen fra Ketting, der endte som præst i Norge. ${ }^{10}$

I Havnbjerg på Nordals virkede i årene 1726-1734 den senere navnkundige Erik Pontoppidan (1698-1764) som sognepræst, men fik med sin pietistiske holdning sognet og nabopræsten på nakken med sine krav om et helligt liv. Af hans skrift Fejekost til at udfeje den gamle surdejg eller levninger af saavel hedenskab som papisme fra 1736 får man indtryk af en bedrevidende præst, der gerne ville belære sin overtroiske, udannede og vildfarne menighed, men savnede evnen til at favne og være i øjenhøjde med almuen. ${ }^{11}$ Så ud af denne højt begavede teologs virke kom der ingen vækkelse.

Stort mere har vi indtil nu ikke vidst om alsisk vækkelse i almuen, og derfor kan det følgende bidrag kaste lys over et forspil, der tildrog sig i Ketting Sogn allerede i 1740'rne, i en periode, hvor den pietistiske kong Christian VI (1730-46) for at fejre jubilæumsåret 1736 og styrke den folkelige fromhed havde indført konfirmationen i hele riget og dermed markeret en reformation af reformationen; men hvor også den samme konges død i 1746 afslørede pietismen som et modefænomen, der stod og faldt med det pietistiske kongehus. Som åndsretning havde pietismen været et frisk pust ind i den lutherske ortodoksis golde læremæssighed, hvor troens vished byggede på det objektivt givne såsom skriftens ord, sakramenterne og kirkelæren. Pietismen, der også byggede på Luther, understregede derimod den personlige erfaring og personlige oplevelse. Man bliver ikke kristen og genfødt ved dåben, men gennem en personlig bodskamp og omvendelse. Omvendelsens virkelighed skulle lægges for dagen i et helligt liv, hvor man afholdt sig fra verdslige fornøjelser. Når omvendelsen fik en sådan betydning, var det nærliggende at kræve en bestemt vej til omvendelsen: Først skulle loven knuse synderen og vise ham, at han var en synder. Dernæst skulle evangeliet oprejse ham og give ham frelsesvished. Adskillige kom aldrig så langt som til dette gennembrud, men blev stikkende i en destruktiv bodskamp og endte i fortvivlelse, og derfor slog pietismen aldrig igennem som en folkelig vækkelse.

Det blev derimod herrnhutismen, der også kaldtes den glade pietisme, der levede videre som lægmandsbevægelse med dens jævne forkyndelse af den Kristus, der tager imod mennesket, som det er, uden at stille krav om bestemte forudsætninger. Det er blevet sagt, at mens pietisten så mere på sin egen elendighed end på Jesu vunder, så den herrnhutiske broder mere på Jesu vunder end på sin egen elendighed. Pietisten talte om alvor og selvprøvelse, hvor herrnhuteren kaldte frelsen en let sag og idel glæde. ${ }^{12}$ Forfulgt af statsmagten og tit også af pøbelen gjorde herrnhuterne det grove forarbejde for den vækkelse og lægmandsbevægelse, der blomstrede op i 1800-tallet.

Det er en del af denne frisættende og folkelige udvikling af gedigen luthersk kristendom, samlet $i$ et sympatisk og følsomt sønderjysk almuesind, som det følgende handler om.

\section{Gode grunde til at leve skjult}

Hvem er denne Peter Ernst, hvis eksistens og virke har været godt og grundigt glemt? Jo, takket være sit nu fremdragne forfatterskab vokser han frem og tager skikkelse. Dog ikke hans ydre, borgerlige fremtoning. 
Den henligger helt bevidst i det dunkle og betyder åbenbart intet. Men forfatterens indre udvikling blotlægges i en sådan grad, at vi får indblik i det, der drev dette 1750 'er-menneske til at sætte pen til papiret. Hvem han var, borgerligt set, hans plads i samfundet, hans familieliv, hans geografiske placering i riget, skal røbes senere. Først og fremmest skal vi, helt i forfatterens ånd, gå på opdagelse i hans åndelige univers og hans bekendtskabskreds, der omfatter Gud og Frelseren Jesus Kristus, mellem venner kaldet Lammet, og alt sammen formidlet af Helligåndens virkende nåde og kærlighed. En opdagelsesrejse på 1. klasse kan man vist godt kalde det.

Eftersom digteren ikke med ét ord røber sin identitet, fristedes jeg i begyndelsen til at antage, at Peter Ernst kunne være et pseudonym. Peter det græske ord petros, betyder "klippe", og Ernst betyder på tysk "alvorlig", og begge ord kunne passe til forfatterskabets karakter. Men når så syv af de salmer, der begynder med bogstavet $\mathrm{P}$, er akrostikon-tekster, det vil sige tekster, hvor det første bogstav i hvert vers er udhævet, så en salme med ti vers har begyndelsesbogstaver, der til sammen danner navnet PETER ERNST ${ }^{13}$, peger alt i retning af, at dette er digterens navn, som han vedkender sig. Akrostikonsalmer var højeste mode blandt de lærde i slutningen af reformationsårhundredet og anvendtes for eksempel hyppigt af Hans Christensen Sthen (1544-1610) i hans salmer. ${ }^{14}$ Det kunne antyde, at også Peter Ernst måtte være en lærd og studeret mand, hvad han også indrømmer på en kryptisk og poetisk måde, når han om sine salmer skriver: "Jeg har lærd og studeret dem ud af Jesu allerhelligste vunder og sår, som er min Bibel. Spørger nogen, hvorfra jeg har bekommet de sange? da svarer jeg: I min frelsers Jesu Kristi fem vunder, hvori jeg læser hver dag. Der er nok at finde for min sjæl, når Jesus er kun i mit hjerte, hvad skøtter jeg om andre ting, hans blod og død, hans ve og smerte, hans vunder og hans sides sting, det er den grund jeg bygger på og kan med alting vel bestå". ${ }^{15} \mathrm{JS}$ blad B $4 \mathrm{r}$.

Man måtte tro, at en sådan lærdom har Peter Ernst vel tilegnet sig på et teologisk fakultet, men eftersom der ikke i gængse opslagsværker findes hverken en sognepræst eller anden studeret person under det navn, iværksatte jeg, efter at være blevet bekendt med bogen i januar 1996, en efterlysning i aviser og tidsskrifter, ${ }^{16}$ og endelig, i januar 2004, gjorde slægtsforskeren Bodil Madsen i Nyord med relationer til Als den overraskende opdagelse, at Peter Ernst var skrædder i landsbyen Blæsborg i Ketting Sogn på Als. En lakune i Kettings kirkebog i perioden 1707-35 afskærer os desværre fra viden om fødselsdato og ægtefælles navn. Men den 26. februar 1741 døbes i Ketting Kirke sønnen Ernst, der konfirmeres i 1757, 16 år gammel. ${ }^{17}$ Og den 30. maj 1793 døde Peter Ernst i Blæsborg, 70 år gammel. Det sidste er næppe rigtigt, eftersom det af forfatterskabet fremgår, både i prosa og poesi, at han var 26 år gammel, da han oplevede sin jordrystende vækkelse i 1744. Så han må være født i 1718, og vi kan altså til næste år fejre den 300-årige digter.

Men hvordan kan vi sandsynliggøre at have fundet den rigtige Peter Ernst? Jo, i et notat fra 1790 hedder det om ejeren af det tredje af ni kådnersteder i Ketting, at "Ernst Pedersen var en Herrnhuter og skrev flere Psalmer og aandel. Sange i denne Retning". ${ }^{18}$ Hjemmelsmanden til denne oplysning må have forvekslet Peter Ernsts førnævnte førstefødte søn med den salmeskrivende far, som på det tidspunkt, tre år før

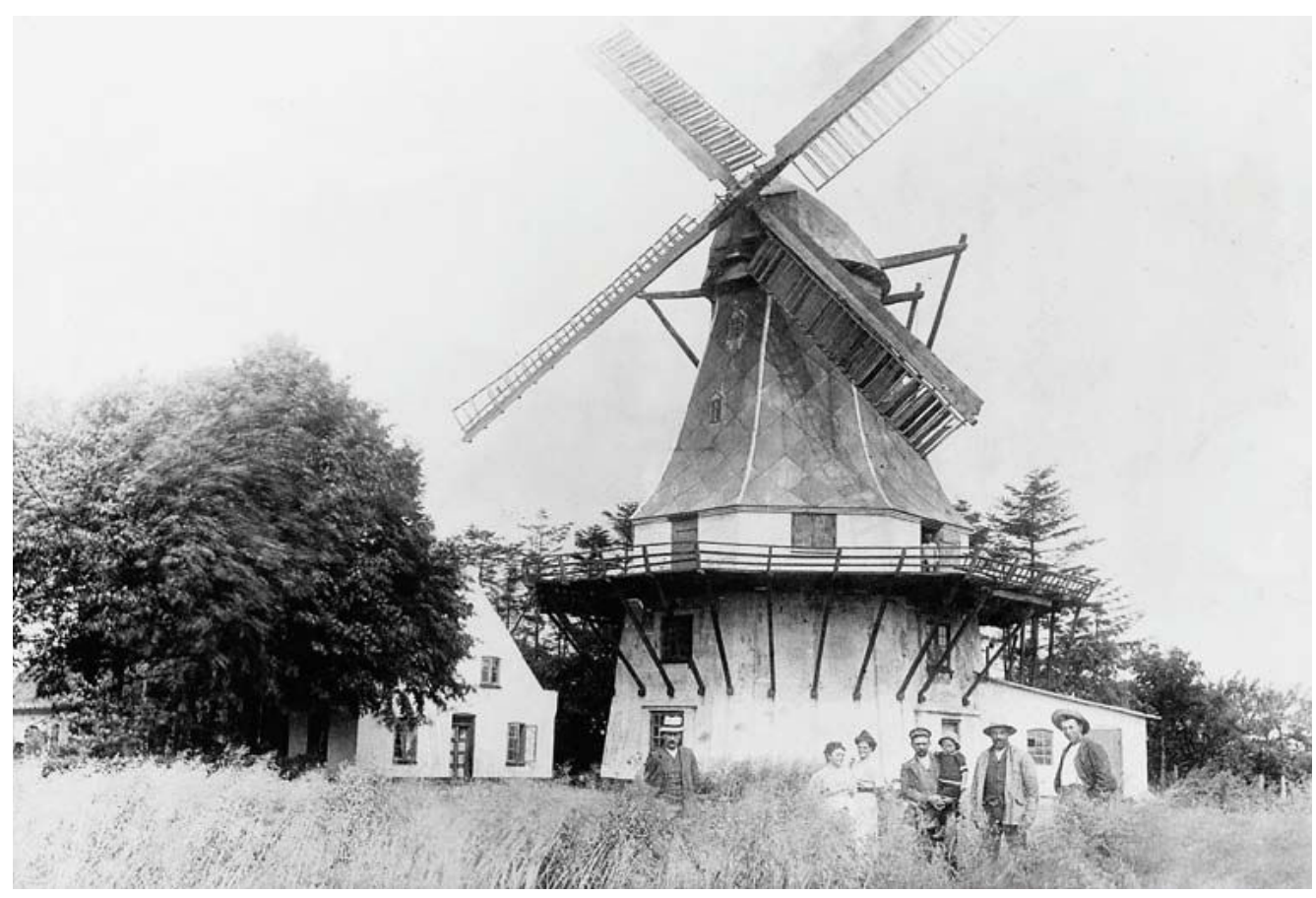

Cirka 1665 lod hertug Ernst Günther en vindmølle bygge på Vrangholm, på den mest forblæste høj, kaldet Blæshøj. Navnet blev senere til Blæsborg. Stedet bestod af fire kådnersteder og et inderstested beboet af en håndvarker eller daglejer. I 1733, ved den tid nersteder og et inderstested beboet af en händværker eller daglejer. I 1733, ved den tid
da Peter Ernst blev konfirmeret, boede Claus Ernst-hans far-ved møllen, der stadig var en stubmølle. I 1854 blev den afløst af vejrmøllen på billedet. Den blev brudt ned $i$ 1942. Foto fra cirka 1912, Lokalhistorisk Arkiv Augustenborg, nr. 019-12. 
sin død, formentlig bor i aftægt hos sønnen. Eller sønnen har måske forhandlet faderens salmer? Vi møder altså her en usikker lokal andenhåndsviden om, at kådnerstedet husede en herrnhutisk salmedigter.

Denne distance til den lokale salmedigter er nok typisk for det forbehold, hvormed Peter Ernst blev mødt af sine egne i Ketting Sogn, da han skejede ud og blev religiøs. Derfor kan det ikke undre, at vi senere møder sønnen Ernst Petersen fraflyttet til landsbyen Elstrup i det herrnhutervenlige nabosogn Egen, hvor Ernst Petersen benævnes skrædder. Han er gået i faderens fodspor. I Egen kan han have lært sættebonden Jørgen Christensen Moes at kende. Han var kirkeværge, da sønnen Peter blev konfirmeret i 1815. Samme år, den 9. juni, døde Jørgen Christensen Moes og begravedes den 13. juni i Egen. Er det en arv efter faderen eller en konfirmationsgave fra skrædder Ernst Petersen i Elstrup, hvori konfirmanden samme år sætter sit navn: "Peter Jørgensen Moes af Igen den 14. Juli 1815"?

Set med vor tids øjne virker det sært, at Peter Ernst aldrig lader et ord falde om sit borgerlige virke i Ketting Sogn. I 1755 og 1756, da han udgiver sine skrifter, er han en gift mand i sin bedste alder med tre sønner, Ernst, Carl Ludwig og Nis, men det véd vi kun fra kirkebogen.

For det første skal vi imidlertid huske på, at den herrnhutiske vækkelse, som Peter Ernst repræsenterede, levede i den dystre skygge af den såkaldte "konventikelplakat", nemlig Den kongelige forordning af 13. januar 1741, om hvorvidt gudelige forsamlinger uden for den offentlige gudstjeneste må tillades. For at få hånd i hanke med gudelige forsamlinger skulle de underlægges præsterne. Ved en gudelig forsamling skal en præst altid være til stede og føre tilsyn med, at der intet sker mod Guds ord eller mod kirkens og statens indretning. Særlig bekæmper forordningen, at nogen forlader deres borgerlige håndtering og under foregivende af at opvække sjæle rejser om fra sted til sted og "bemænger sig med læreembedet, hvortil de hverken har Guds eller menneskelig kald". I november 1744 fulgte en ny forordning, der mistænkeliggør dem, der henter uddannelse i Herrnhut, og et reskript fra december 1746 forbød de hjemlige herrnhutere at indkalde fremmede skolemestre til at undervise deres børn. ${ }^{19}$ Repressalierne fortsatte, og foranlediget af gejstligheden pålagde over-konsistoriet i Slesvig i 1762 Tønder magistrat at inddrage alle "Herrnhutiske Psalmer af fordægtigt Indhold", som måtte ligge hos byens bogbindere og bogførere. ${ }^{20}$ Så i den forbindelse har Tønders øvrighed gennemført en razzia i Reinholdts trykkeri, hvor Peter Ernsts skrifter formodes trykt.
Sådanne forordninger kan være grund nok til, at Peter Ernst går stille med dørene og ikke skilter unødigt med sin person. Samme forsigtighed gør sig gældende i det anonymiserede brev fra Norge, som han aftrykker i forordet til JS.

For det andet har Peter Ernst ikke fundet anledning til at inddrage sit borgerlige liv i et forfatterskab, som dybest set er et anliggende mellem den korsfæstede Jesus og en benådet synder, der har modtaget digtningens nådegave. Det er den blodige frelser, det er målrettet Kristuskoncentration, det drejer sig om, hver gang Peter Ernst fører sin pen til papiret.

\section{Betragtninger over barndom, konfirmation og ungdom}

Digterens vej til Frelseren hører vi om. Detaljeret sker det i fortalen til samlebindets tredje skrift, hvor han beretter om anfægtelser, vægelsind og eftertanke i en barndom og ungdom, der fører frem til den store afklaring: "Denne lille bog kalder jeg Hjertets Bekendtskab med Gud og Lammet. Af den årsag, at den handler om hvorledes jeg er kommet i bekendtskab med Gud og Frelseren Jesus Kristus". De derpå følgende betragtninger over barndom og ungdom er nedfældet af den 37-årige Peter Ernst i april 1755. Han har nu fundet sit ståsted og har fundet ligesindede, med hvem han kan dele anfægtelser og glæder. Men dengang må han have været mutters alene med alt det, han gik og tumlede med. Dilemmaet er ikke blevet mindre, da han efter sin første nadver trådte ind i de voksnes rækker, besøgte "værtshuse og spillede, dansede og holdt sig lystig" og spejlede sit eget liv i de verdensmennesker, "som holdt sig smukt og præsenterede sig honnet". Fra landsbyen Blæsborg var der halvanden kilometer til Augustenborg Slot, hvor det pragtlystne hertugpar Christian August (1696-1754) og Frederikke Louise (16991744) udfoldede et anderledes liv i overvældende luksus med festlige arrangementer og glade mennesker omkring sig. Som amtmand over Sønderborg Amt og med titel af guvernør over Als havde Christian August siden 1732 magten samlet i sin person, altså en ret så "honnet" herre. Til de sociale kontraster mellem Blæsborg og Slottet har for Peter Ernst føjet sig kontrasterne mellem hans egen samvittighedsnagende følgagtighed med flokken "på mørkhedens vej" og pietismens ideal om en bodskamp under angst for fortabelse og et krav om omvendelse væk fra verden. Og her må konfirmationsforberedelsen med dens nærgående krydsforhør til det inderste i konfirmandens sjæleliv have spillet 
en vigtig rolle. I Peter Ernsts hukommelse har dette gennemborende spørgsmål i hans katekismus bidt sig fast: "Har du holdt noget af Guds bud og befaling? Ja, noget: Gud ske lov for sin nåde. [...] Da kom det svar: Ak nej! du har intet holdt, om endskønt du har holdt noget udvortes. Så er dog dit hjerte fuldt af alt det, som er imod Guds lov!" Takket være det præcise citat fra Peter Ernsts katekismus kan vi nu slå fast, at i Ketting Sogn har præsten (eller degnen) ved Peter Ernsts konfirmation undervist i den luthersk-ortodokse Jørgen Lauridsen Aaskovs Catechismi Børns Aandelig Melck og Tyggemad, 1679, en pædagogisk anlagt udlægning af Luthers lille katekismus, formet i enfoldige spørgsmål og gensvar. ${ }^{21}$ Sandsynligheden taler for, at Aaskovs katekismus har været i brug i Ketting, siden den begyndte at udkomme. Peter Ernst må være konfirmeret i perioden 1732-35 og før konfirmationens indførelse i hele riget den 13. januar 1736. I hertugdømmerne var konfirmationen indført allerede sidst i 1600-tallet. I 1734 havde præsten i Ketting, Johannes Mathiesen Poulsen Plate, været i dette embede i over 50 år og blev i 1710 tillige provst over Als Søndre Herred. ${ }^{22}$ Skal man bedømme kettingprovstens teologi og forkyndelse ud fra katekismen, må han have været talsmand for den ortodoksi, man kalder ortopraksi, det vil sige nidkærhed for såvel den rene lære som det rette og praktiske kristenliv. ${ }^{23}$ Dette har været konfirmandens åndelige bagage.

Om sin videre åndelige udvikling beretter Peter Ernst, at han indså, at han ikke var "af den flok, som elsker Jesus af hjertet". Men han har en fortrøstning til, at Jesus ikke forgæves har rørt ved hans hjerte på tusinde måder i hans ungdom, så vel ved syndige selskaber som i kirken under sangen og ved klokkernes lyd. Særlig ved indstiftelsesordene rørtes hans hjerte: "Det var ligesom jeg kunne se, hvor Jesus sad til bords med sine disciple og åd påskelammet. Ja, det var som jeg kunne høre, hvorledes han sang: Ak, hvor var det en vigtig sag for mig. Hans skikkelse var klar for mig. Han ligesom stod for mig og lod mig beskue den store kærlighed, som han havde til mig."

Overvældet af dette himmelske syn bryder Peter Ernst ud i vers:

"Ak, den søde himmelmund, sang for mig i denne stund.

Ak, de søde ord jeg kan høre af min Frelsermand.

Det jeg aldrig glemmer nu, det skal stå udi min hu,

hvor min frelser rørte mig med sin kraft så underlig.

Skønt jeg er en fattig sjæl, har jeg dog i Lammet del,

i hans vunder jeg vil stå, og Guds nåde altid få."
Til de følgende iagttagelser af nattehimlen over Als kan man jævnføre med Brorsons samtidige "Op! al den ting, som Gud har gjort" og de tanker, som nattehimlen over Tønderegnen kalder frem i et digtersind: "Hvad skal jeg sige, når jeg ser/ hvor stjerne-flokken blinker", og når Brorson endnu højere oppe skuer "den store kæmpetrop af blide engleskarer". Der er den samme enfoldige forundring over skaberværket $\mathrm{i}$ den alsiske yngling, og også hos ham aktiveres den poetiske åre:

"Når jeg gik ud sildigt om aftenen, og det var klart i luften, da så jeg altid op til himmelen og beskuede stjernernes mangfoldighed og tænkte ved mig selv: Deroppe i Himlen sidder vor Herre i stor herlighed, hvor englene og de udvalgte sjæle lover hans navn. Der sidder Frelseren med sit forklarede legeme. Ak, kunne jeg også nå den lykke at indkomme for hans blide ansigt og se de hellige vunder, som han har til min salighed. Fremdeles når jeg hørte tale om den yderste dag, blev jeg bange. Når jeg hørte om helvede, tænkte jeg på den elendighed, som der er for de fortabte sjæle. Ak min Gud, frels mig dog, og lad mig finde din nåde i mit hjerte."

Dette hjertesuk slår umiddelbart over i poesi og afføder disse vers:

"Hver sjæl, som bor i Jesu sår, er fri og uden fare står.

De tør ej frygte nogen nød, kan skade dem i liv og død. Derfor så vil jeg nu ret glad, beskytte mig i den fristad, som er i Jesu sides sår, hvor jeg i evighed består.

Ved Jesu fod jeg finder læ, og når jeg ser på korsets træ, da hænger du min frelser der, og har mig i dit hjerte kær. Tak! Jesus, for du søgte mig, og rørte hjertet inderlig. Tak! for din nåde o min mand, som du på mig nu vender an."

Kirkegang og nadverdeltagelse har bevæget hans unge sind og fremmanet Frelseren for både hans indre blik og øre, og disse bevægelser eller visioner omsættes - adskillige år senere - til poesi. Naturen med nattehimlen og stjernernes mangfoldighed minder ham ikke kun om Guds eksistens, men om Frelserens bolig og lykken ved at få del heri. $\mathrm{Og}$ vejen til Frelserens hjerte og de frelstes fristad går gennem Frelserens sidesår. På den vision bygger han sit håb og det budskab, som han udtrykker i sin digtning. Denne vision daterer Peter Ernst til året 1744, så vi må formode, at hvad han beretter i HB, hører hjemme i tiden in- 
den det religiøse gennembrud. Således også de følgende episoder, som er bemærkelsesværdige ved deres rigdom på opmærksomme iagttagelser, klare analyser og opbyggelige følgeslutninger:

\section{Billedet i købmandens stue}

"Engang kom jeg ind i en købmands hus og satte mig ned i stuen. Og som jeg så mig om, da blev jeg opmærksom på et billede, hvorpå jeg så en lang tid med fornøjelse. Thi det var meget sælsomt [rart] at se: Der var et stort bjerg, som var ganske højt, og oven på toppen stod et hus. Og Frelseren gik op ad bjerget til huset og bar et kors på sin ryg, men en hel hob folk fulgte ham lige efter, og enhver af dem bar et kors. Nogle havde det på ryggen, og nogle i armene, og nogle slæbte det, som de bedst kunne". ${ }^{24}$

Peter Ernst beretter, at der var mange folk i stuen, så snakken har sikkert været livlig om alt muligt andet, men han sidder stille for sig selv og kan slet ikke få øjnene væk fra det billede. Og han fortolker "dette skønne billede", idet han ser sig selv i flokken af korsbærere på vej op ad bjerget Golgata og op imod huset, som må være det nye Jerusalem. HB s. 9-11.

Efterhånden kommer det kristne fællesskab til at spille en større rolle i Peter Ernsts univers. Han møder trosfæller, der deler hans glæde ved Frelseren. De omtales som "Guds børn og sande oplyste sjæle" og

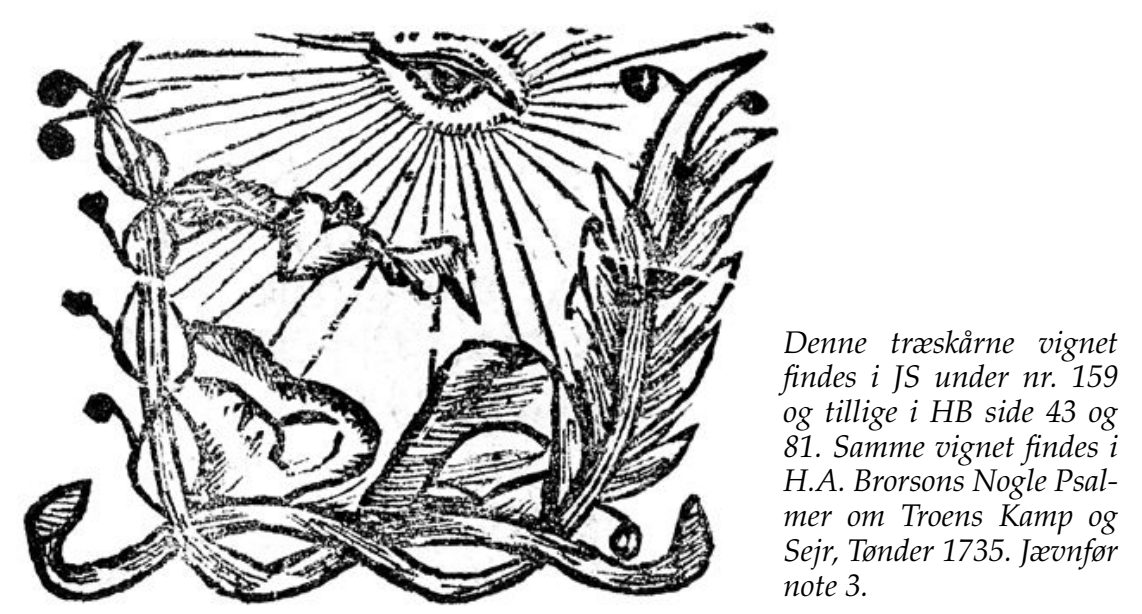

"hellige brødre og søstre", og i den modgang, som deres trosfællesskab møder fra statskirken og fra den rå pøbel, er de hinanden til gensidig opmuntring:

Søskende i Jesu blod,

Står kun fast på troens fod ...

... Vi er nu beseglet alt,

Jesus har os i gevalt,

Jesus er vor store præst,

$\mathrm{Nu}$ vi holder jubelfest,

Jesus Kristus er os næst.

Vi har Herrens ånd og sværd,

Vi er af de himmel-lærd',

$\mathrm{Nu}$ vi synger Lammets sang

Så det gir en yndig klang,

Vi blir renset og gjort fri,

Jesus baner livets sti,

Synd og død vi går forbi.

Nr. 68 str. $14-16$

Vi skal lægge mærke til betegnelsen "himmellærde" om de herrnhutiske brødre og søstre. Om sit eget forhold til sine salmer skriver Ernst, at han har "lærd og studeret dem ud af Jesu allerhelligste vunder og sår, som er min Bibel". JS blad 4r. Her taler et menneske, der er sig bevidst at tilhøre den sande kirke, der bygger på den sande lærdom, himmellærdommen, hvor "Jesus er vor store præst". Modsat den falske lærdom, repræsenteret af statskirkens præster, der er lærde og studerede i den hellige skrift og den foreskrevne teologi, men mangler en levende tro. Disse åndløse præster, der af staten er sat til at forvalte kirkens nådemidler, har ved kongelige forordninger fået til opgave at agere vagthunde over for den folkelige vækkelse. Men eftersom forordningerne ikke tillader lægfolket at kritisere præsterne, må kritikken pakkes ind i bibelske gevandter. Som det umiskendeligt sker i disse vers om ypperstepræsternes forhør af den fangne Jesus skærtorsdag nat, nr. 95:

Her står du for de lærde mænd og er for disse ret ukendt.

De vide skriften, men Guds Lam

de kender ej, det er en skam. 
Ak, hvordan har de præster lærd, det er jo ganske rent forkert at vide skriften og ej se på denne søde frelsere.

At vide skriften uden ham, det er en evig spot og skam, det er en lærdom ganske slet, som ses jo af de præster ret.

Hvor mange lærde er der ej, som vandrer på den mørke vej?

Et billed har vi her at se,

de præster gør kun Jesus ve.

Så går det og i denne tid,

man lær, studerer ret med flid,

men Jesu vej forbi de går

og følger ej hans fodespor.

Gud lære mig og hver en sjæl

at kende den Immanuel,

som stod i striden mandelig

og skænkte os sit himmerig.

Det præstespejl, det "billed", der i denne salme fokuserer på de falske præster, afsluttes med at udpege de rette præster, der kender den stridende Kristus, der skænkede os himmerig. Og så er vi tilbage ved den søskendeflok af uforfærdede og troende kristne, som bekender, at "Jesus er vor store præst".

Vi ville gerne have vidst mere om, hvem disse stærke og standhaftige trosfæller var, og derfor er det uvurderligt, at Peter Ernst med nogle vellykkede snapshots lader os møde et par af disse anonyme samtidige personligheder: "Efter nogen tids forløb kom jeg ved en lejlighed til at tale med en retskaffen [rædelig] hustru, som var oplyst af den Helligånd på Jesu død og blod". Hun fortæller Peter Ernst om sine bekymringer og anfægtelser, men "da kom der en røst i hendes hjerte, som sagde "Det er betalt", nemlig Jesus havde betalt for alle hendes synder". For hende var vejen fri og åben til Jesus, og hun erklærede, at vi havde samme adkomst til Helligånden som de hellige apostle! "Hun var så munter og glad i Herren, at jeg forundrede mig derover". Når Peter Ernst betroede hende sit hjertes uro, var hendes fornøjede reaktion: "Morgenstjernen Jesus Kristus frembryder nok i dit hjerte med sine klare stråler. Jesus med sit blod (håber jeg) skal funkle i din sjæl". Og Peter Ernst lader sig berolige og rive med af hendes glæde: "Her kunne jeg erfare, hvorledes Frelseren Jesus fører sine børn. Den ene sjæl glæder sig over den anden, og det var mig til stor velsignelse, og efter den tid har vi talt tit og ofte derom med hverandre og glædet os i Herren vor Gud, som gik i døden for os". HB s. 11-12.

Fra Herrnhut udgik emissærer eller udsendinge til Danmark og Norge, gerne ægtepar, "søskendepar", således koldingenseren Gert Hansen og hans hustru. I 1742 kom "søskendeparret" skomager Vitus Bering Handrup og hans hustru Maria Bruun og i foråret 1745 den mæhriske tømmersvend Andreas Grasmann og hans hustru Rosina Jäscke. Deres faste base var Stepping Præstegård. Der var bud efter dem mange steder fra. Særlig Andreas Grasmann påkaldte sig opmærksomhed som en personlighed ud over det vanlige. For biskop Brorson i Ribe øvede Grasmann sjælesorg, da denne troede at have syndet mod Helligånden. ${ }^{25}$ Emissærerne foretrak samtalens form på herrnhutisk vis således, at han talte med mænd og hustruen med kvinder ${ }^{26}$ Om det har været en ledsagende hustru, Peter Ernst omtaler som den "hustru", han har mødt, kan ikke siges. Næppe, hvis reglerne skulle overholdes. Snarere er der tale om en vakt kvinde fra Als, siden de efterfølgende "tit og ofte" talte med hinanden om Frelseren. I denne fase i Peter Ernsts åndelige udvikling finder han omsider ligesindede.

\section{Skoleholderen og Brorsons salmebog}

En anden unavngiven sønderjysk personlighed, som Peter Ernst præsenterer os for, er en skoleholder, med hvem han oplever en åndelig samstemthed. De skoleholdere, der betjente rytterskolerne, havde ellers ikke det bedste lov. Duelige skoleholdere var sjældne, for lønnen var ikke tillokkende. Blandt bønder var det at undervise børn kun noget, man gav sig af med, hvis man ikke duede til andet eller var arbejdssky. Således klagede præsterne i Als Søndre Herred 1745 over manglen på rette skoleholdere, "thi de som nu gør profession af skoleholdelse, er ikkun fuskere [Bønhaser], håndværksfolk og daglønnere". ${ }^{27}$ Fem år senere bønfaldes kongen af skoleholderne i Søndreherred, fordi de 
endnu ikke har fået en skoleforordning at indrette undervisningen efter. Og endnu i 1760 klager to skoleholdere i Egen over en manglende skoleforordning. ${ }^{28}$ Så derfor bidrager følgende skildring til at nuancere dette kun negative billede. ${ }^{29}$ Tillige får vi et tidligt vidnesbyrd om brug af Brorsons Troens rare Klenodie fra 1739, og episoden må derfor dateres til tidligst dette år: "Ved en anden særdeles lejlighed kom jeg til en skoleholder, som var en gudfrygtig sjæl. Han havde et besynderlig stille væsen på sig". Peter Ernst drages til ham og forsøger længe at kontakte ham og tager endelig mod til sig og betror ham sine anfægtelser og sit hjertes uro, hvortil han svarer:

"Min broder, du må nok se til, hvorledes dit hjerte er beskaffen: Om du søger Frelseren og skænker ham dit hjerte. Thi han har dyrt købt dig med sit blod. Bed dag og nat til Gud, for Jesu døds skyld, at du kan vorde en synder, som har sin bolig i Jesu blodige vunder. [...] Denne tale var mig ret kær og kom mig til stor velsignelse. Han læste også nogle salmer for mig af Brorsons salmebog om omvendelsen..$^{30} \mathrm{Og}$ efter den tid fik vi ét sind og talte med hverandre om Herrens vej. En halv dag om sommeren var for os som to timer, så fornøjeligt var det at handle om Frelserens sag. Og han tog mig med sig hist og hid, hvor han gik til andre retsindige [rædelige] sjæle, og vi var glade i Herren. Tilforn bad jeg så tit en bøn, når klokken slog ${ }^{31}$ og havde også visse salmer at synge om morgen, middag og aften. Når det var sket, fandt jeg i mit hjerte en besynderlig rolighed." HB s. 13-15.

\section{Født på ny til liv i Kristus}

Det er i skriftet JEsu Saar og Vunders Frygt, der tryktes i 1756, at vi præsenteres for Peter Ernsts "Nye Psalmer eller Messianiske Sange", også her med et forord.

Den skelsættende begivenhed i Peter Ernsts liv indtræffer i året 1744, i hans 26. år, da Frelseren opvakte ham af syndens søvn og drog ham til sig gennem en sand omvendelse og syndserkendelse, der gav ham en sådan kraft og opmuntring, at han fyldtes af "Herrens lov og pris for sin søns godhed og venlighed, så at jeg skrev nogle rim eller vers derom med et kridt på bordet. Og da jeg så dem an, da var de meget vigtige i mit hjerte, hvorover jeg satte dem på et papir med en pen år $1745^{\prime \prime}$. JS blad A 3.

Det fremgår ikke entydigt, hvori vækkelsen i året 1744 består. Er det digterevnerne, der forløses, da han med kridtet på en tavle i skrædder- værkstedet nedfælder de første rim til Frelserens pris, der er det synlige udtryk for den forunderlige afklaring? Forundret som den unge fugl, der opdager, at den kan flyve ved at sprede vingerne ud, oplever skrædderen, at han er blevet salmist: "Jeg vil synge, Herre, om din kraft og blodige nåde, du retfærdige Gud og frelser. Som Moses og Israels børn sang en dejlig lovsang, da de var frelste ". JS blad A 5. Og han ser sig tilbage over de bibelske sangere David, Salomon, Jeremias og Jesus selv, der sang med sine disciple.

Kristenlivet udfolder sig i sang. Klarheden kommer til ham, springer frem af de vers, der falder ind i hans hjerte: "Når jeg gik på en vej for mig selv, da kunne jeg synge, ligesom ordene faldt mig ved. Og jeg mærkede mig dem og skrev, når lejligheden kom, thi hjertet var fuldt af den Helligånds salve både nat og dag." JS blad A 3. Digteren fører dagbog over både sin sindstilstand og tilblivelsen af salmer, hvoraf enkelte er dateret. For eksempel skriver han, at i "år 1749 blev jeg endnu nøjere bekendt med Frelseren, hans åbenbarelse med sine vunders glans blev mig ganske ny, [...] hans arme omfavnede mig med kraft, hans mund kyssede mig med glæde og fred, så at jeg gjorde nogle vers og sange derom, og især disse. Jeg stod engang og tænkt mig om etc. [nr. 133] Halleluja! Gud, og vort Lam etc. [nr. 72] Lam: der du mig vakte etc. [ nr. 129]."

Om året 1753 beretter han, at det begyndte med "sang på sang om Lammets blodige sved og vunder i et kærligt samfund med andre Guds oplyste sjæle og søskende i Kristus". Han har altså fundet ligesindede, med hvem han i sang kan dele det bedste, han véd.

Hvis man skal sammenfatte den erkendelse, der fremgår af hans digtning, kunne det blive, at vejen til Frelserens hjerte går gennem hans sår, især det sidesår lige under hjertet, som førte til hans død på korset.

Hav tak for dine vunder,

o! kærlighedens lam, dit blod det gør mig munter,

det frier mig fra skam.

Det gør, at jeg går lige frem

til Gud min lyst og glæde

i ny Jerusalem.

Nr. $160^{32}$ str. 16 .

Jesu død på korset er en kærlighedserklæring, og findes der større udtryk for kærlighed end at sætte alt sit eget, ja sætte sit liv til for sin elskede? 
Når jeg hans fattigdom besér og alt hvad han mått' lide, mit hjerte da af glæde lér midt udi sorg og kvide.

Det gi'r i sjæl og hjerte mod at være sænkt i Jesu blod og i hans åbne vunder.

Nr. $163^{33}$ str. 11 .

Kun syndere kan gennem sidesåret finde vejen til Frelseren. Og derfor bliver Peter Ernst aldrig træt af at betone nødvendigheden af den glade syndserkendelse, der er vejen til frelsen. For eksempel "Udi hans vunder, der er rum/ til dig, o synder, kom! o, kom! / Lammet du skal leve" Nr. 150 str. 2.

Det er ham magtpåliggende, at hans sange indgår i den kæde af vidner, af martyrer, der ned gennem historien har lovsunget Frelseren. Derfor ser han tilbage over salmedigterne i fortiden for der at hente legitimitet for sine hjertelige lovsange til Jesu blodige vunder. Han peger på den bøhmiske martyr Jan Hus, der har sunget og bedt "Jeg råber til dig, o Herre Krist, jeg beder du høre min klage, giv mig den rette tro forvist, at jeg dig ikke forsager" ${ }^{\prime \prime 4}$. Jan Hus sang ikke med læberne alene, men hans sang kom fra hjertet. Derfor søgte han hen til Frelserens blodige vunder og sår. Og af Luthers salmer fremhæver Ernst "Krist lå i dødsens bånde" om det blodige offerlam, som Luther besynger: "Her er det rette påskelam/ om hvilket Gud haver budet/ det er det, som på korset kom/ for vor skyld stegt og dødet/ dets blod stænkes på vore døre/ og holder døden uden fore/ den morder [mordener] kan os ej røre/ Halleluja!"35

Til denne kæde af salmister føjer Ernst nu sig selv: "Hvor ringe, liden, og syndig jeg er i mit hjerte, så har Gud dog anset det og udøst sin nådes virkninger deri formedelst Jesu blods klarhed. Han er den sol, som har bestrålet mit hjerte, Han er den morgenstjerne, vort hjerte oplyser så gerne, med sin miskundheds ord". Det sidste er citat fra den reformatoriske "Herre Krist Gud Faders enbårne søn". "Om ham", fortsætter Ernst, "vil jeg synge, fornøje mig, i ham vil jeg glæde og fryde mig [...] Om der skulle findes nogle, som vil bespotte mine ringe sange, da vil jeg bede for dem til Gud, at de må se, at det er Guds ord og værk,[...] thi det er en frugt af Jesu død og forsoning, et vidne om det Lam som bar verdens synder. Hvor klare de [salmerne] har været i min sjæl, kan jeg ikke beskrive for nogen, men det må føles og erfares." JS blad A 6-8.
Træskåret Lam med glorie $i$ en røskenramme, dobbelt foroven og forneden. I JS over nr. 105. Til indramningen er anvendt fire typer roskener, der optro typer roskener, der optra er i bogtrykker Johan Anthon Reinholdts Biblisk Haand-Bog, Tønder 1757. Røskener $i$ venstre og højre ramme genfindes $i$ Biblisk Haand-Bog s. 78, 207 og 561. De to inderste rekker 561. De to inderste rækker oroven og forneden anvendes s. $268,384,461,484$ 518 og 565. De to yderste rækker med tovsnoning anvendes s. 449, 488, 503, 534 og 535. Samme tovsnoning $i$ Johan Peter Brorsons Billigste Veeklage, Tonder (Reinholdt) 1757 på titelbladet. Jxunfor note 3 .

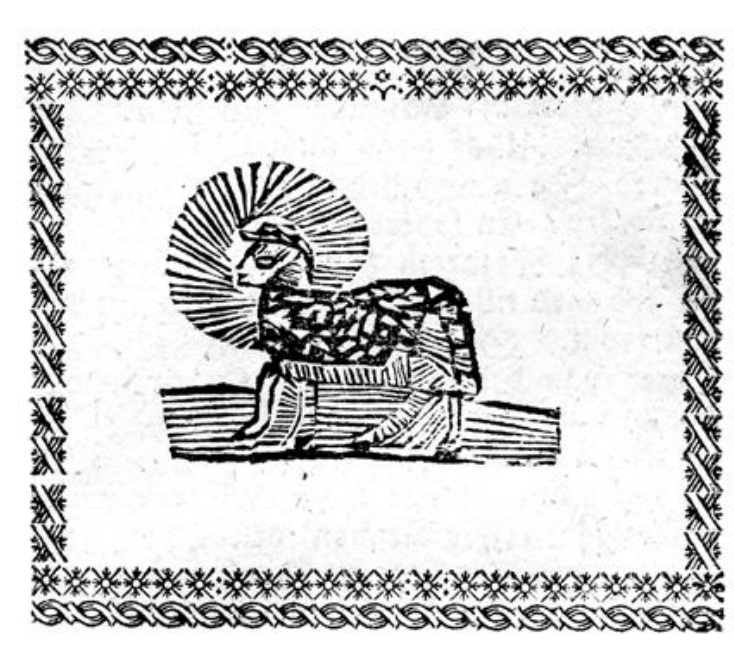

"Af Guds nåde er jeg, hvad jeg er og hans nåde imod mig har ikke været forgæves", skriver Paulus i 1 Kor 15,10. Det er den samme blanding af ydmyghed, taknemmelighed, forundring, henrykkelse og selvfølelse, der møder os i Peter Ernsts skildring af sin vej til lovprisningen af Lammet:

"Se, o menneske, hvilken fylde den korsfæstede Gud har givet mig, af sin nåde, for hans døds skyld, se! De dejlige og velsignede salmer, Gud han har begavet mig med [...] Se, mine søskende i Herren, se den søde frelser, som jeg fremviser i disse sange, [...] Jeg forundrer mig derover, at så mange sjæle har antaget disse salmer med stor respekt og ærbødighed".

Det lader til, at Peter Ernst forud for de nu fremdragne skrifter har udgivet salmer, formentlig som skillingsviser, som har fundet god afsætning, og retsindige [rædelige] sjæle tog dem til sig "med begærlighed". Der var til gengæld andre, som ikke "fandt smag i dem", hvorved han blev mindet om "Frelserens ord, når han siger: En profet gælder intet i sit eget fædreland Matt 13,57." Anerkendelsen er især kommet "på andre steder vidt borte, hvor der er et dejligt vidne aflagt om dem" 
og som eksempel herpå aftrykker Ernst et brev, som en broder uventet har sendt ham fra Norge og med de samme ord og vendinger, som kendetegner den herrnhutiske lidt svulstige stil:

"Min i Lammets blod og vunder meget kære broder Peter Ernst vores blodige mand velsigne dig inderlig

Dine arme synderes blod og vunders sange er mig til hænde kommet ganske uformodentlig, hvorfor du skal have hjertelig tak. De er mig med min kære hustru og de få søskende her ret kære og angeneme. Frelseren lade dem også blive os til velsignelse. Hvad Frelseren fremdeles vil give dig nåde, drift og velsignelse til at lade fremkomme, ville du også værdige os at nyde del i, det kan ske med de tvende kære venner, som bringer dig dette, hvilke agter sig hid tiere, min lille kære Broder, jeg tror du ikke tager min dristighed ilde op, at jeg tager mig den frihed til at skrive dig disse få linjer til, men jeg kan ikke andet. Jeg har ret et fuldt hjerte til dig, og det første dine sange kom mig for øje, fandt jeg en hjertelig højagtelse, respekt og ærbødighed for den ånds kraft og nåde, dig er meddelt, som også en hjertelig kærlighed til din person, fordi du er også et af Lammets får, [...] uagtet jeg ikke vidste, hvad eller hvem du var af stand og vilkår, jeg føler et samfunds og forenings bånd i mit hjerte mellem dig og mig, samt alle dem, som henhører med os til Lammets side [...] Hjerte broder, hils hjertelig alle dem hos dig, som i sandhed elsker Frelseren, [...] næst hjertelig hilsen fra min kone vil jeg hermed hilse og kysse dig i min ånd og omfavne dig i Lammets sides hule ved den blodige nåde, din ringe dog elskende broder. Lev vel ved vunderne Amen.

L. den 22 Juni 1754. M.C." JS blad B 2-3

Af citatet fra Matt 13,57 må vi konkludere, at salmerne ikke slog an i Ketting og omegn, men vandt indpas længere borte. Vi får indblik i det netværk, som brødre og søstre i rigets to lande havde sammen. Særlig om den førnævnte koldingenser Gert Hansen og hans hustru véd vi, at de rejste hemmeligt ud som emissærer, og at Gert Hansens succesrige virke i Norge var den direkte anledning til konventikelplakaten i $1741 .{ }^{36}$ Det kunne være dette ægtepar, der er de "tvende kære venner", som overbringer brevet fra Norge. Det fremgår af brevet, at Peter Ernsts person er brødrene i Norge aldeles ubekendt. At pejle sig ind på den anonyme norske afsenders identitet kan være vanskeligt og skal være det, for kloge af skade var det herrnhuternes strategi at lægge et røgslør ud for at kunne virke som de stille i landet. Den lever godt, som lever skjult. Vi får kun lokaliteten "L" og initialerne "M.C." at pejle efter. "L" kunne være Larvik, hvor sognepræst Ole Tidemand virkede 1734-1743 og vakte en skare, der for en del gik over til herrnhuterne. Gert Hansen virkede netop i Larvik. To gange om året rejste emissæren Erik Brau og hans hustru ud fra Drammen, hvor de i 1746 havde etableret et brødresocietet, og besøgte blandt andet Larvik og holdt forsamling dér. ${ }^{37} \mathrm{En}$ anden lokalitet kunne være Lista, hvor der opstod en vækkelse, så det hed sig, at halve Listerland var herrnhutisk. ${ }^{38}$ Hvem dækker så initialerne M.C. over? Det kunne være Michael Crøger, der gjorde sig bemærket i Drammen som en ægte herrnhuter allerede i 1742, da der endnu kun var få, der "kunne betro sig til Lammet". Han var også på færde i Skien i 1741 og kaldes da "den ivrige og meget kritiske broder". ${ }^{39}$

\section{Konklusion}

Peter Ernst har med mangfoldigheden af sine salmer, skrevet til en mangfoldighed af melodier, leveret os et enestående vidnesbyrd om noget, som er ved at ske i midten af 1700-tallet. En opvågnen, en vækkelse i en stivnet statskirke, der styres af teologisk uddannede præster, der ligesom de ypperstepræster, der dømte Jesus, "kender Skriften, men Guds Lam/ de kender ej, det er en skam." I modsætning til disse lærde jubler Peter Ernst over de "himmel-lærde", de brødre og søstre, som han deler sin tro med, og som har Jesus til præst.

Vi møder en mand af folket, der efter en åndelig vækkelse dukker frem af anonymiteten og giver sig til kende. Det er ellers almuemenneskets lod at blive overset og glemt. Men her er den sjældne undtagelse, hvor vi får indsigt $i$ hans inderste tanker, tilmed omsat til lidenskabelig poesi. De første spæde forsøg efter sin vækkelse eller som en del af vækkelsen gjorde han på sit skrædderværksted med kridt på et bord, men snart blev kridtet erstattet af pennen og pennen sat til papiret, og af den mageløse opdagelse af vejen til den korsfæstede frelsers hjerte gennem hans blodige sidesår voksede der et forfatterskab frem. Eller udtrykt voldsommere og sikkert sandheden nærmere: En tsunami af blodige, glade og overgivne salmer sprøjter ud af skrædderens pen og sætter skel mellem den sande og den falske kirke: 
Når andre fort med verden går

og haver syndig glæde,

da holder vi os til hans sår,

der er vort bedste sæde.

Vor glæde er den frelser sød,

som blodig var på korset død,

ej anden vi vil have.

Nr. $164^{40}$ str. 4

Den sidste linje svarer, bevidst eller ubevidst, til Luthers "der er ej anden Gud" i "Vor Gud han er så fast en borg" (Salmebogen nr. 336 str. 2,8) og minder os i jubilæumsåret om, at Peter Ernst er sig bevidst, at han i kirkens lange kæde af Kristus-sangere også og ikke mindst er forbundet med reformatoren og hans glade og stærke Kristussalmer. Peter Ernsts salmer vidner om springet fra knugende pietisme til befriende herrnhutisme.

\section{KILDER}

\section{Utrykte kilder:}

Det Kongelige Bibliotek, Center for manuskripter og bøger, NkS (Ny kgl. Samling):

\section{LITTERATUR}

Appel, Charlotte: Læsning og bogmarked 1600-tallets Danmark I-II, København 2001.

Brodersen, J.: Fra gamle Dage. Det kristelige livs vakkelse og vakst $i$ Nordslesvig fra begyndelsen af Brodremenighedens mission til henimod midten af 19. aarhundrede, København 1912.

Bruun, Jens: Barselstue og Himmelstige. Samlede digte og salmer af Løjt-degnen Hans Mikkelsen (1720-1796), Aabenra 1991.

Buch-Petersen, Elsebeth: Bogtrykkerivirksomheden $i$ Tonder 1731-1770 \& 18131853, København 1974

Ehrencron-Müller, H.: Forfatterlexikon omfattende Danmark, Norge og Island indti 1814 I-IX, København 1924-1932.
2683 4to Knudsen, Christian: Topographiske Samlinger til de alsiske Sognes Historie, XI. Deel, dateret 3. 12. [18]61 (Øe Als' historie og beskrivelse, bind 11).

Fink, Torbjørn: Herrnhuternes betydning for norsk kristenliv på 1800-tallet. Oslo 2010 (https:// www.duo.uio.no/handle/ 10852/32831)

Heiberg, Knud: "Brødremenighedens Virksomhed i Sønderjylland før Kristiansfelts Anlæggelse. Stepping Præstegaard", Kirkehistoriske Samlinger, 5. rk. II 1903-1905, s. 611-624

Henningsen, Lars N.: Værdikamp og folkeuro. Bønder, præster og øurighed i 1790 'ernes Slesvig, Aabenraa 2016.

Henningsen, Lars N.: "Den fuldkomne monark", Skalk, nr. 6, december 2002 s. 28-31.

Henningsen, Lars N.: "Da kronprins Frederik gjorde en buk", Slesvigland, 23. årg. 2002, s. 37-45.
Henningsen, Lars N.: "Landsbylærer i Asserballeskov og Bovrup 1750-1785 - a Johannes Pades erindringer", Sønderjyske årbøger 2000, s. 77-148.

Japsen, G.: Det dansksprogede skolevxsen Sønderjylland indtil 1814, Tønder 1968.

Koch, L.J.: Salmedigteren Brorson. En Mindebog til Tohundredaaret for hans Julesalmer, København 1932

Larsen, Grethe: "Johann Anthon Reinholdt, Tønder 1753-70". I Erik Da (red.): Danske Provinstryk 1482-1830: en bibliografi IV, København 1998, s. 119122.

Larsen, Jørgen: Sønderjyllands Kirkehistorie, København 1946.

Lindhardt, P.G.: Konfirmationens Historie Danmark, København 1936.

Lundbye, Jørgen: Herrnhutismen i Danmark. Det attende Hundredaars Indre Mission, København 1903.

Lyster, Jens: "Hvem kender Peter Ernst?", Hymnologiske Meddelelser, 25. årgang, 1996, s. 68-69.

Lyster, Jens og Jens Høigaard (udg.): Hans Christensen Sthens Skrifter I-IV, København 1994-2015.

Neiiendam, Michael: Erik Pontoppidan Studier og Bidrag til Pietismens Historie I, København 1930.

Nielsen, Rita Bromand: "Blæsborg Mølle", Arsskrift 2000, Lokalhistorisk arkiv for Augustenborg og omegn, s. 33-34

Paulsen, H. Hejselbjerg: Sønderiydsk Psalmesang 1717-1740. Fra Egidius til Pontoppidan: en kirkehistorisk undersøgelse Christiansfeld 1962

\section{NOTER}

1 Honi soit qui mal y pense! Indskrift på den eftertragtede engelske hosebåndsorden.

2 JEsu Saar og Vunders Frygt. det er Nogle Nye Psalmer Eller Messianiske Sange, Bygt paa de hellige Patriarchers, Propheters, Apostlers, og Lutheri grundvold Som er Jesus Christus Jacobs Gud, og Israels Frelsere hoilke er Eenfoldig af den Hellig Aand, I kraft Formedelst det ord Om JEsu
Pedersen, Johannes: "Pietismens tid 16991746". I Hal Koch et al.(red.): Den Danske Kirkes Historie V, København 1951 s. 7-229.

Pontoppidan, Erik: Fejekost til at udfeje den gamle Surdejg eller de $i$ de danske Lande tiloversblevne og her for Dagen bragte Levninger af saavel Hedenskab som Papisme, 1736, København 1923.

Rørdam, Holger Fr.: "Herrnhuterne i Randersegnen i Christian VI's Tid", Kirkehistoriske Samlinger, 5. rk. I, 1901-03, s. 493-523.

Schrøder, Urban: "Løjt-degnen Hans Mikkelsen som salmedigter og andre iagttagelser over et håndskrevet salmehæfte", Sønderiyske Årbøger, 1965, s. 181-203.

Thrap, Daniel: Brødremenigheden i Norge, Christiania 1908.

Thyssen, Anders Pontoppidan: "De $x$ ldre jyske vakkelser. Brødremenigheden i Christiansfeld og herrnhutismen i Jylland til o. 1815" I Anders Ponen i jylThys til o. 1815 Inders Pontoppidan Thyssen (red.): Vrekkelsernes frembrud $i$ drede IV, København 1967.

Thyssen, Anders Pontoppidan: Vækkelse, kirkefornyelse og nationalitetskamp i Sønderjylland 1815-1850 VII. København 1977.

Thyssen, Anders Pontoppidan (udg.): Personalhistoriske, sognehistoriske og statistiske bidrag til en dansk præste- og sognehistorie: 1849-1949 10A, København 1977-85.

Treschow, Gerhard: Danske Jubel-Larere, København 1753.

Øverland, Per: Herrnhuterne i Norge, Trondheim 2005.

Død I en Levende kundskab, og kiendelse ved GUds Naade, i Lammets Blods kraft og hans hellige Vunders hemmeligheders virkninger, Lys og Glands, erfaren og forrestillet af P. Ernst. Trykt $i$ Aar 1756. Bogtitler og citater i øvrigt er i nærværende bidrag gengivet med moderniseret retskrivning og med stiltiende rettelser af trykfejl og misvisende tegnsætning. Den forestående udgivelse af hele Peter 
Ernsts forfatterskab er derimod en nøjagtig gengivelse af originalteksterne men med forklarende noter.

3 Tønder var i Nordslesvig det tidlige centrum for skillingsviser og billige tryk. Trykkeren af JS og HB kan være Johann Anthon Reinholdt, der virkede i Tønder i årene 1753-70 og overtog materiel fra andre tønderbogtrykkere. En vignet $(57 \times 40 \mathrm{~mm})$ i HB s. 115 med frugter og ranker findes også i Biblisk HaandBog, Tønder (Reinholdt) 1757 [Tø 56] s. 614. Over nr. 105 i JS træsnit: Indrammet lam med glorie $(75 \times 64 \mathrm{~mm})$. Røskene i rammens venstre og højre side identiske i Biblisk Haand-Bog s. 78, 207 og 561 Træsnittet har dobbeltramme foroven og forneden. Den inderste ramme er en røskenrække identisk med den i JS 133 mellem nr. 182 og 183. Den er identisk med røskenfrise i Biblisk Hand ido tisk 384 Vignet $(67 \times 35 \mathrm{~mm})$ med blombog s. 384. Vignet $(67 \times 35 \mathrm{~mm})$ med blomste s. 174 i HB (umiddelbart før registeret) afbildes i (unide Ægidius En Nye Psalme-Bog, Tønder (Reinholdt) 1755 [10 52]. Afsluttende vignet i JS efter nr. 159 og genbrugt i
HB s. 43 og 81 er et træsnit (55x44 mm) HB s. 43 og 81 er et trasnit (55x44 mm) med et himmelsk øje, hvorfra det straler ned over blade og planter. Samme
træsnit i H.A. Brorsons Nogle Psalmer træsnit i H.A. Brorsons Nogle Psalmer om Troens Kamp og Sejr, Tønder (Vajsenhuset, Herman Hinrich Rotmer) 173 [Tø 5], aftrykt i Buch-Petersen 1974, 19. Træskåret frise med englehove $(65 \times 27 \mathrm{~mm})$ i HB s. 141 identisk i Joha Christian Fabricius' Kurtzer Unterrich Tondern (Waysen-Haus) 1738 [Tø 32], Buch-Petersen 1974, s. 48. Under nr. 62 JS som vignet to liggende, modstillede røskener, der også er klummepryd i HB s. 23-174. De findes identisk i Fabricius" Kurtzer Unterricht s. 32. Under nr. 83 JS tre blomsterrøskener, identisk som klummepryd i Fabricius' Kurtzer Unterricht s. 4-32. Da Tønder magistrat i 1762 på gejstlighedens initiativ foretog en trykkeri for at inddrage herrnhutiske salmer af fordægtig indhold, var fuglen (Peter Ernst) sikkert NfPs er næppe trykt af Reinholdt.

4 Nr. 3 str. 4, nr. 85 str. 11, nr. 119 str. 6-9,

Nr. 3 str. 4, nr. 85 str. 11, nr. 119 str. $6-9$,
nr. 156 str. 17, nr. 159 str. 2, HB s. 138 str. 12-21; s. 142 str. 7.
5 Peter Ernst kan fra kilder med tilknytning til Augustenborg Slot have været godt orienteret om Frederik V's uduelighed som regent og hans uheldige livsførelse med skandaliserende deltagelse i orgier i det københavnske natteliv. I alt fald er det påfaldende, at almuedigteren Peter Ernst slet ikke komme i nærheden af det forløjede skønmaleri hvormed det officielle Danmark fremstillede denne konge, der pristes for sin fortræffelighed, sine dyder og visdom Han var "den fuldkomneste monark", han var alles forbillede i dyd (Henningsen 2002 i Slesvigland og Skalk). Peter Ernsts anliggende er at være sandheden tro i kærlighed, hvorfor kongen ikke hyldes med ét ord, men kun omgærdes af forbøn og bønner om, at Gud vil lære ham at elske Lammet og brødrene og fri ham fra syndens far or relligånden påmindens fare og lade Helliganden paminde ham, năr han gør fejltrin. Peter Ernst kan sammen en særlig mission $i$ vedholdende forbønner for kong Frederik V.

6 Nogle faae Psalmer, Om en arm Synderes Naades Gang og Pleye hos den tro Hyrde Vor Korsfeste Frelsere. forfattede af P. E.

Imprimatur in fidem Protocolli Facultatis Theologicæ JOH OTTHO BANG Dr. Professor Hans Otto Bang (17111764) så med sympati på herrnhutere Det københavnske Brødresocietet dagbøger gav ham ved hans død det skudsmål, at han "elskede Brødrene", men ikke ejede mod til for alvor at kæmpe for deres sag. Så vidt Bjørn Kornerup i Dansk Biografisk Leksikon, II 1933, s. 83.

8 Hiertens Bekiendskab med Gud og Lammet det er Et vidne om GUds kierlighed, oo Naade, formedelst vor Frelsers JEsu Christi Blod og Hellige Saar og Vunders Salve. Erfaren af den HelligAands Oplysning JEsu Blods og Lidelses kraft, Og eenfoldi forestillet I en levende Troens Erkiendelse, forestillet I en levende Troens Erkiendelse, GUd, I den Kor so

9 Tilsvarende herrnhutiske vækkelser omend lidt senere, er kendt fra Løjt Sogn, hvor den begavede, digtende Sogn, hvor den begavede, digtende og 1796) un degn Hans Mikelsen (1720tisk sindede sognepræst i Løjt, Christian
Bendixen (1754-1781) får et kald som salmedigter (Schroder 1965, s. 189-200; Bruun 1991, s. 11 f). Jørgen Hanssen (1732-1819) fra Ragebøl i Dybbøl Sogn var fra barndomshjemmet påvirket var fra barndomshjemmet påvirket af
pietismen og trådte senere, som gårdejer i Sottrup, i forbindelse med herrnhuterne og skrev digte $i$ en pietistisk tone (Henningsen 2016, s. 281-283). dybbølpræsten Hans Balsløvs tid fra 1754 til 1795 var der en betydelig herrnhutisk indflydelse, og flere tilhørere fik under hans prædikestol et åndeligt gennembrud (Henningsen 2016, s. 281).

10 Brodersen 1912, s. 523-527; Thyssen 1977-85, s. 715 og 736; Thyssen 1977, s. 23 og 173 .

11 Neiiendam I, 147-152; Pontoppidan 1923, 1-68

12 Pedersen 1951, s. 208; Lindhardt 1936, s. 28.

13 Nr. 57: Paa Lammet staaer min' tanker, mel. Hielp Gud, at jeg nu kunde; nr. 66 = HB s. 140: Paa Messianisk viis jeg nu vil leve, mel. Hvo som vil salig; nr. 78: Paa Sielen min Guds Søn skal bløde, Paa Sielen min Guds Søn skal bløde, mel. Naar sielene sig; nr.128: Prissærfødt os Jesus Christ; nr. 131: Priis lof, og føat os Jesus Christ; nr. 131: Priis lof, og tak, Skee dig o! Lam, mel. Et Barn er født i Bethlehem; nr. 153: Prophet Esaiam, Han Ligner Gud sin Frelser, mel Udi Gethsemane; HB s. 164: Piint er min Frelser sød, mel. Udi Gethsemane.

14 Se Hans Christensen Sthens Skrifter bind I s. $66-68,69-71,78-79$, bind II s. 149 172-174, 301-303, 387-394, 425-435, bind III s. $105,282-283$, bind IV s. 57-59, 145

15 Denne tilsyneladende beskedenhed udelukker ikke, at Peter Ernst har været litterært orienteret. I HB s. 47 citere han fra "Gyld Skat-Kiste p. 350", som er den netop udgivne Carl Henrich Bogatzkys En Gylden Skat-Kiste for Dem som soge at have et Liggende-fx $i$ Himmelen, 1754, med Enevold Ewalds fortale len, 1754, med Enevold Ewalds fortale dateret 18. februar 1754. IHB s. 48 citeSieg Bette pag. 367.

16 Lyster 1996 s. 68-69.

17 Kettings kirkebog meddeler også den 17. februar 1743 dåb af Peter Ernst Skræders søn Carl Ludwig. Og i 1765 kom altå sonnen Nis, 17 ar december 1753 begraves Claus Ernst på Blesborg, 70 år gammel, Peter Ernsts ar. Den 29. oktober 1762 begraves hans mor, 66 år gammel. Aret forinden, den 20. marts 1761 begraves Peter Ernstes [hustru] Blæsborg, 62 år.

18 Knudsen NkS (Ny kgl. Samling) 1861 For denne og andre henvisninger takker jeg Bodil Madsen, Nyord.

19 Pedersen 1951, s. 200-204 og 208

20 Paulsen 1962, s. 299.

21 Bogen må have været efterspurgt, siden den if. Ehrencron-Müller 1924, s. 24-25, genoptryktes i 1687, 1692, 1698 og 1708. For identificeringen af citatet der findes i udlægningen af det 10. bud s. 62 i Aaskovs katekismus 1679 , takker jeg cand.theol. Finn B. Andersen. Aaskovs katekismus inddrages og citeres i Appel 2001, bind I s. $181 \mathrm{og}$ 183-184 som dokumentation for 128 færdighed hos almuens ungdom.

22 Treschow 1753, s. 319.

23 Lindhardt 1936, s. 23-24.

24 Motivet med korsbærende kristne som udtryk for Kristi efterfølgelse er almindelig kendt. Men præcis det billede, formentlig et kobberstik, som Peter Ernst så i en sønderjysk, måske alsisk købmands stue, har jeg hidtil efterlyst forgæves i danske museer og kunst- og billedsamlinger. Derfor udlover jeg et eksemplar af den forestående udgave af Peter Ernsts samlede skrifter til den der leder mig på sporet af billedet. Henvendelse til jensblyster@gmail.com

25 Koch 1932, s. 126-133; Heiberg 19031905, s. 616-621.

26 Lundbye 1903 s. 107-114. Om ægteparret Handrops ophold i Jyllland, der afsluttedes med en udvisning af riget ved en forordning af 20 . november 1744, handler Rørdam 1901-03.

27 Japsen 1968, s. 134.

28 Japsen 1968, s. 135. positivt billede af Hans Jørgen Pades gerning som skoleholder i Asserballeskov, der dog forst fandt sted $i$ årene 1749-1763, dog forst fandt sted $i$ arene der er i spil i Peter Ernsts ungdom.

30 I Troens Rare Klenodie har det tredje afsnit i Den anden Part af Troens Grund overskriften "Om Omvendelsen" og rummer 11 salmer. 
31 Som gammel kristelig sædvane anføres i En liden Haandbog som indeholder allehonde nyttige Offuelser vdi Gudelighed, 1578, en række "klokkebønner" i Hans Christensen Sthens Skrifter, II, 2003, s. 314-315 og 319 linje 58-69, jf. bind I, 1994, s. 28-30. Udbredt var også "En kort bøn at bede hver time, når klokken slår" i Rasmus Hansen Reravius' En liden Bønebog, 1575.

32 til melodien "Hjælp Gud, at jeg nu kunne", der anvendes syv gange af Ernst.

33 til melodien "Hvad kan os komme til for nød", der anvendes 15 gange af Ernst.

34 Denne salme er fra reformationstiden og kan næppe tillægges Jan Hus, men tilskrives ham undertiden sidst i 1600-tallet. Således i Daniel Paullis Dend Siungende Guds-Fryct, 1680, s. 468, og i Kingos Gradual, En Ny Almindelig Kirke-Salmebog, Odense 1699 blad R $1 \mathrm{v}$ og i nogle tidlige udgaver af Kingos salmebog.

35 Ernst citerer ikke fra Pontoppidan pietistiske salmebog fra 1740, der skriver "den mordere". Ernst læser "den mordener" ligesom reformationstiden salmebøger og Kingos salmebog. Således også i Paullis Dend Siungende GudsFryct, 1680, der betegner salmen med Luthers initialer D.M.L

36 Fink 2010, s. 22.

37 Fink 2010, s. 21; Thrap 1908, s. 6, 12-14, $36,65-66$.

38 Øverland 2005, s. 39.

39 Thrap 1908, s. 11 og 13

40 til melodien "Hvad kan os komme til for nød".

\section{Zusammenfassung}

Bisher hat man gemeint, die Glaubenserweckungen auf der Insel Alsen hätten erst ungefähr 1770 stattgefunden. Aber ein Buchfund auf einer Mülldeponie in Guderup auf Alsen hat diesen Zeitpunkt um einige Jahrzehnte verschoben. Ein Sammelband mit drei unbekannten herrnhutischen Schriften aus den Jahren 1755-56 von einem unbekannten Dichter namens Peter Ernst, wohnhaft in der Gemeinde Ketting auf Alsen, gibt wertvolle Einsichten in die religiöse Entwicklung und der schliesslichen Bekehrung des sechsundzwanzigjährigen Mannes im Jahre 1744. Er erlebt eine wundersame Klärung aus dem reuigen und niederdrückenden Pietismus zu einem fröhlichen Herrnhutismus. Eine zuvor nicht bewusste Fähigkeit als Dichter wird erlöst, und ein Tsunami von blutigen und ausgelassenen herrnhutischen Liedern spritzt aus seinem Gänsekiel. Er betrachtet seine blutigen Lieder als lutherisch berechtigt. Die Melodiehinweise auf seine ungefähr 180 Lieder beziehen sich zumeist auf die alte dänische Liedertradition und nur sieben auf das Liederbuch der Brüdergemeinde. Er berichtet über eine Verbindung zu gleichgesinnten Brüdern und Schwestern, sogar in Norwegen, die seine Lieder mit Dankbarkeit entgegengenommen haben.

Eine Ausgabe der ganzen Verfasserschaft ist zur Herausgabe im Jahr 2018, dem 300. Jahr seit seiner Geburt 1718, unter Vorbereitung.

\section{Fra helgenbillede i Kevelaer til kistebillede i Haderslev}

\author{
Et eksempel på konfessionelt betingede \\ ændringer af et billede ${ }^{1}$
}

Af Helge Clausen

I Haderslev findes to varianter af et religiøst billede fra slutningen af 1700-tallet af Jomfru Maria og Jesusbarnet. De befinder sig henholdsvis i den katolske Sankt Marie Kirke og i Museum Sønderjylland. Det kan påvises, at billedet stammer fra et andagtsbillede fra 1642 i den tyske valfartsby Kevelaer. I analysen og fortolkningen af billedet inddrages derfor elementer af den katolske teologi om Jomfru Maria. Kevelaerbilledet må være blevet indført til Haderslev, men før det blev genudgivet her, har det undergået visse forandringer for ikke at komme i konflikt med den lutherske teologi. Der sammenlignes med eksempler på kirkelige tekster og kirkekunst, som har været igennem den samme procedure.

\section{Indledning}

Trykte billeder fra tiden mellem reformationen og Grundloven i 1849 af Jomfru Maria med Jesusbarnet, hvor der forekommer tydelige katolske symboler, er usædvanlige på vore breddegrader. Der findes dog en del sådanne billeder, der ovenikøbet er trykt i det lutherske Danmark, som på den tid reagerede på næsten alt katolsk med skepsis, afvisning og forbud. Hvordan kan det så være, at billeder med tydeligt katolsk indhold ikke blot fandtes i den danske konges riger og lande, men også blev trykt her?

I et forsøg på et besvare dette spørgsmål bliver et bestemt billede af denne type analyseret med henblik på en fortolkning i lyset af dets historiske og kulturelle baggrund. Billedet, som er trykt i Haderslev og foreligger i flere varianter, undersøges for at fastslå dets ægthed og oprindelse. Dele af den katolske teologi om Jomfru Maria og den kirkehistoriske situation i det 17. og 18. århundrede i Nordeuropa inddrages som forståelsesramme.

Ud over de to eksemplarer af billedet, som i dag befinder sig i Haderslev, udgøres kildematerialet af breve mellem den danske folkemindeforsker, Johannes Evald Tang Kristensen og samleren af kistebilleder, 